\section{DIGITAL COMMONS \\ @ UNIVERSITY OF SOUTH FLORIDA}

\section{ABO: Interactive Journal for Women in the Arts, 1640-1830}

Volume 2

Issue 2 Volume 2.2 (Fall 2012): Open Access

Article 4

2012

\title{
Hard Times: Women Scholars and the Dynamics of Economic Recession
}

Julie Candler Hayes

University of Massachusetts-Amherst, jhayes@llc.umass.edu

Follow this and additional works at: https://digitalcommons.usf.edu/abo

Part of the Dramatic Literature, Criticism and Theory Commons, Educational Methods Commons, Feminist, Gender, and Sexuality Studies Commons, and the Literature in English, British Isles Commons

\section{Recommended Citation}

Hayes, Julie Candler (2012) "Hard Times: Women Scholars and the Dynamics of Economic Recession," ABO: Interactive Journal for Women in the Arts, 1640-1830: Vol.2: Iss.2, Article 4.

http://dx.doi.org/10.5038/2157-7129.2.2.4

Available at: https://digitalcommons.usf.edu/abo/vol2/iss2/4

This Scholarship is brought to you for free and open access by Digital Commons @ University of South Florida. It has been accepted for inclusion in ABO: Interactive Journal for Women in the Arts, 1640-1830 by an authorized administrator of Digital Commons @ University of South Florida. For more information, please contact digitalcommons@usf.edu. 


\section{Hard Times: Women Scholars and the Dynamics of Economic Recession}

\section{Keywords}

advocacy, American higher education, defending the humanities, state of the profession, women's leadership in higher educatoin

Creative Commons License (c) $($ ) $\Theta$

This work is licensed under a Creative Commons Attribution-No Derivative Works 3.0 License. 
When I think about "the dynamics of economic recession," my thoughts turn not just to women scholars, but to all scholars in programs that are threatened with cutbacks, to institutions, and of course to students. The deprofessionalization of academic labor and the increasing reliance on contingent faculty are part of this picture. I am however going to frame my remarks in terms of two large categories:

1. Defending the Humanities (enlisting students)

2. Institutional sites for defending the Humanities (women in administration)

There are many ways to consider the "defense of the humanities" and there is a burgeoning literature on the subject. I am going to focus on one very pragmatic way, which rests on the assumption that strong, high-performing, academic programs are easier to defend than disciplines in the abstract when programs are weak. And of the multiple characteristics of strong programs, I would suggest that programs are strong and students are drawn to them when the students are intellectually stimulated and confident in the value of their studies. (I'm simplifying for the sake of a general argument. I focus on undergraduate major programs, since that tends to be where the trenches are drawn to protect faculty lines; the pragmatic defense of graduate programs would invoke other criteria, notably job placement—in both academic and non-academic careers.)

I don't doubt that our programs are intellectually stimulating, but I am not so certain that we have always given students the resources that they need to articulate their practical significance. All too often we hear students say that (for example) they pursue a literature major "for love" and a business major "to get a job." We can do better than that.

I was looking recently at a book by Mark Roche titled Why Choose the Liberal Arts?. Roche sees three "partly overlapping" arguments in favor of the liberal arts:

- The intrinsic: the joy of exploring the life of the mind and "asking the great questions that give meaning to life" (pg).

- The practical: "the cultivation of those intellectual virtues that are requisite for success beyond the academy, a liberal arts education as preparation for a career" (pg).

- The idealistic: "character formation and the development of a sense of vocation, the connection to a higher purpose or calling" (pg).

Roche is speaking of the liberal arts in general, which include—we shouldn't forget-the sciences—but I'll confine my remarks to the humanities.

We've long assumed we had a lock on Roche's "intrinsic" argument and perhaps his "idealistic" argument as well, though many in this secularist age shy from references to a "higher purpose." Although we are sometimes accused of neglecting the practical dimension of students' education, I don't actually think that to be true: but we often offer glib pronouncements about the utility of critical thought without actually making it explicit either through our teaching or the structure of our curricula. We should not blithely assume that undergraduates are able to see the connections between, say, their 
ability to analyze an eighteenth-century French novel and the professional world that they plan to move into. We should give thought to that question and ask our students to think about it as well. Which is not to say that we should focus solely on Roche's second point, but ask students to be mindful of their own progress and development in the "intrinsic" and "idealistic" dimensions as well. We should be making these points at every level of the curriculum, including (and especially) in our so-called "service" or general education courses. As Renata Miller puts it, "The long-term benefit would be nothing short of a citizenry educated in the ideas that we in the humanities most value.”

To articulate the relevance of our intellectual work, both our teaching and our scholarship, is not to surrender to the dark forces of instrumentalizing reason. I would hope, actually, that I am preaching to the choir and that we share a deep commitment to the notion that our work contributes to our students' welfare and to the public good. But we cannot take that notion for granted or assume that it is as transparent to students, their parents, and members of the public in general, as it is to us.

Case in point: the heightened awareness of educational cost. According to which analysis you read, student loan debt either already exceeds credit card debt or will soon exceed it; either way, it is expected to surpass one trillion dollars this year. As you may be aware, a high proportion of student loan debt and student loan defaults can be laid at the feet of the for-profit educational sector. Why would students-generally first-generation or older "non-traditional" students - opt for these expensive programs? Because, despite statistics to the contrary, they believe that career-oriented degrees and certificate programs will lead them to well-paid jobs more effectively than a four-year undergraduate liberal arts degree. Meanwhile, despite the fact that surveys continue to show that college graduates have a significantly increased earning potential over non-attendees, ${ }^{1}$ we continue to see claims in the media - and by politicians - that a college education is not necessary to a middle-class lifestyle, not worth the cost, etc.

If we discount these threats or assume that our students will somehow figure it out on their own and naturally integrate the critical thinking skills learned in our literature, history, philosophy, or art history courses into their pursuit of a career-or maybe I should use the less glorious term, “job”- then we are doing them a disservice and ourselves as well.

My college-Humanities and Fine Arts - currently offers a one-credit course that helps students recognize and develop their skills (or "intellectual virtues requisite for success beyond the academy" [citation]) and articulate them in the job search. It's taught by the "student success coordinator" in our advising office. It's very hands-on, and we've been discussing ways to scale it up and make it available to a larger number of students than the eighteen or so happy few who hear about it. I would like for us to find ways of integrating some of these insights more broadly into the curriculum-not to instrumentalize the areas of study, but to the contrary, to help students understand their value and be able to express that value to the world. I call this, "defending the humanities from the ground up.” 
Otherwise, we face the prospect that the humanities (and fine arts) will become increasingly viewed as irrelevant to the concerns of the many, the province of the elite few whose socio-economic background offers them a greater guarantee of professional employment regardless of undergraduate major. In that case, we have failed in what I see as a key aspect of our mission as scholars and intellectuals, which is to educate for democracy.

If we are truly educating for democracy, then it behooves all of us to be sensitive to the changing economic and demographic environment of higher education. As many of you are probably aware, the college-age population is becoming increasingly diverse. It is projected that by 2020, the population of white, non-Hispanic high school graduates will have declined to just over half of the graduating class, and that decline will continue. Colleges need to be paying attention to the factors that enable different ethnic groups to succeed-historically, this is not something that many of our institutions, particularly the elite liberal arts colleges or the research-intensive universities, have done very well. Economically, the "high-fee high-aid" model that many institutions have pursued is proving unsustainable for all but the wealthiest institutions, and assumes - counter to demographic projections - a steady, substantial number of students able to pay full tuition; aid in the form of grants puts pressure on institutional budgets, while aid in the form of loans increases student debt.

"What is to be done?" Some analysts call on us to accept that research and liberal education will be possible only at a few elite private institutions while the rest of us will educate the masses via online certificate programs, following the "disruptive innovation" of the for-profit sector. I don't accept that vision of the future, but I think it likely that we will find ourselves there (or our current grad students will) unless we put some creative thought into ensuring that a good education remains both widely available and affordable. New pedagogies enabled by technology have a role to play. So does political action, lobbying to stop the public disinvestment in higher education-but in order for lobbying efforts to be successful, we'll need to show that we are on the right path.

Obviously, there is much to be said about all of this, but I want to take my last few minutes to get to a second broad topic, which I suppose could be thought of flippantly as "defending the humanities from the top down." By which I mean, making the decision to move into college and university administration, "going over to the dark side" as people like to call it.

I never thought I had the makings of a public intellectual or the inclination to become one, but I still remember the unpleasant surprise of learning what the average print run of a scholarly monograph at a top-tier university press was and realizing that this was not how I would change the world. That realization coincided with the beginning of my first term as department chair, and although I never put the two together until I began preparing these remarks, I suspect that it contributed to my awareness that chairing could be a significant and personally satisfying intellectual project. Which is not to say that I loved my scholarly work the less - with the exception of a great sabbatical year in 200405 and the year that immediately followed it, all of my 2009 book was written while I 
was a department chair. Chairing is also a marketable skill, and the most likely way for most of us to change institutions after tenure. And it is good preparation for other administrative positions.

It isn't so far, it turns out, from chairing a large multi-lingual department to being a dean, and I hope that some of you who never thought about it before today will start thinking about it now. Because despite the remarkable gains women have made in the professoriate since 1970, they are under-represented in the upper echelons of higher administration.

- Nationally, women are 57 percent of all college students (and receive $60 \%$ of undergraduate degrees conferred) but they represent only 26 percent of full professors, 23 percent of all presidents, and 14 percent of presidents at the doctoral degree-granting institutions.

- Despite the growth of women in the academy, the number of female presidents has not changed in the last 10 years (White House Project).

The pipeline exists, but it is moving slowly.

- Women (of all races/ethnicities) made up 45\% of senior administrators and 38\% of chief academic officers. (Only a small percentage of these are people of color.)

Significant opportunities exist. According to ACE's The American College President: 2007 Edition, almost half of all college and university presidents in 2006 were age sixtyone or older. If half of these individuals choose to retire in the next five years, onequarter of college presidencies will become vacant.

I hope that we will see more women taking on leadership roles in every type of institution. There is a great deal to be said about the nature of administrative work, its peculiar pleasures and challenges, and how one can prepare oneself for administrative positions-through departmental and institutional committee work as well as through workshops and training institutes such as those offered by Higher Education Resource Services (HERS). If we feel strongly about the fate of our institutions (and our disciplines), if we wish to bring management styles more often informed by an ethic of care rather than the spirit of competition, then administration is one way to begin to achieve our goals. 
Resources and Further Reading

American Council on Education (ACE) Women's Network. Resources and publications: http://www.acenet.edu/Content/NavigationMenu/ProgramsServices/Leadership/Inclusive ExcellenceGroup/Programs/ACENetwork.htm

AAUP resources for women in higher education: http://www.aaup.org/AAUP/issues/women/

Córdova, Diana I. “Moving the Needle on Women’s Leadership.” (pipeline issues) On Campus With Women, 40.1 (spring 2011). http://www.aacu.org/ocww/volume40 1/data.cfm (This issue of OCWW is devoted to articles on women and academic leadership.)

Gerdes, Eugenia Proctor. "Women in Higher Education Since 1970: The More Things Change, the More They Stay the Same.” Advancing Women in Leadership Online Journal, vol. 21 (Summer 2006). http://www.advancingwomen.com/awl/summer2006/Gerdes.html

HERS (Higher Education Resource Services). Leadership development for women administrators. http://www.hersnet.org/

Misra, Joya, Jennifer Hickes Lundquist, Elissa Holmes, and Stephanie Agiomavritis, “The Ivory Ceiling of Service Work.” Academe 97.1 (2011 jan-feb.). http://www.aaup.org/AAUP/pubsres/academe/2011/JF/Feat/misr.htm

Women in Higher Education (online journal). http://www.wihe.com/default.jsp Includes useful list of web resources.

Women in Academia (quick statistics) http://www.catalyst.org/publication/327/womenin-academia

\section{Works Cited}

American Council on Education (ACE) Women's Network. Resources and publications: http://www.acenet.edu/Content/NavigationMenu/ProgramsServices/Leadership/In clusiveExcellenceGroup/Programs/ACENetwork.htm

Georgetown Center on Education and the Workforce, http://cew.georgetown.edu/).

Miller, Renata Kobetts, “A Mid-Career Feminist Reflection,” Academe 97.1 (2011), 
http://www.aaup.org/AAUP/pubsres/academe/2011/JF/Feat/mill.htm.

Roche, Mark. Why Choose the Liberal Arts? Notre Dame IN: University of Notre Dame

Press, 2010.

“The White House Project Report: Benchmarking Women’s Leadership” (November 2009), 9, http://www.thewhitehouseproject.org/documents/Report.pdf.

June, Audrey Williams, "Pipeline to Presidencies Carries Lots of Women, Few Members of Minority Groups," Chronicle of Higher Education (February 15, 2008).

\footnotetext{
${ }^{1}$ It is true that the unemployment rates differ according to college major; recent liberal arts graduates have a higher unemployment rate than graduates in applied disciplines. However, the unemployment rates even out considerably for people several years beyond the degree and are in any case lower than the national unemployment rate (Georgetown).
} 